\title{
Obituary: Brian Lee
}

\section{DAVID MURRAY* AND RICHARD H. KING*}

Brian Lee, who died in December (after a short illness) was one of the key figures in the development of American studies in England. Brian was born in 1932 near Blackpool. After two years' National Service in the army in Egypt he studied English at Bristol University, going on to do postgraduate research on Henry James, on whom he later published. He became a lecturer in the English department at Nottingham and proceeded over a long career at Nottingham (he retired in 1993) to develop American studies, from modules within the English Department to joint and single honours degree courses in the late 1960 s, and eventually to an independent department which became one of the largest in the country. This was a hard-won struggle, and many would have become discouraged by the institutional and sometimes personal resistance and obstruction he encountered. This was based partly on a complacent and ignorant anti-Americanism that publicly questioned whether there was enough American culture or history to be worth studying and privately sniped about "Mickey Mouse" courses. Structurally the difficulty in developing American studies or any interdisciplinary initiative at the older universities stemmed from the rigidity of the departmental system. At the time there was at least the illusion that academics did actually decide things themselves. This meant interminable faculty board meetings at which all the details of curriculum had to be justified to staff in English or history departments who had never had to justify in any way the rationale for their own, often ramshackle, courses. Nevertheless, Brian doggedly pushed on and won the arguments, aided by the resounding popularity of the subject with students.

These were exciting times, in that developing the department went hand in hand with developing the subject itself. Reflecting the background and training of most of the staff, American studies began with the twin pillars of literature and history, but one of Brian's virtues was an intellectual openness and enthusiasm for interdisciplinary ventures on American culture and thought which

* Department of American and Canadian Studies, University of Nottingham. Email: Richard. King@nottingham.ac.uk; david.murray@nottingham.ac.uk. 
eventually became central to the subject at Nottingham. In particular he was always open to popular culture and personally developed within the department courses on film studies, which grew to the point where another separate department was eventually formed. He was always open to new ideas, and was a leading figure in an innovative Erasmus network, with conferences and teaching exchanges with European universities, and played an active role in editing the successful BAAS Pamphlet series.

With hindsight it is easy now to see the American studies course as it was originally taught was deeply exclusionary in terms of race and gender and much else besides (though this was remedied as we developed strengths in Native and African American studies and in race and rights). It was certainly deeply canonical, but it is worth remembering that what was canonical in the US was, in an English context, far from it. The subject seemed accessible, popular and often transgressive, and students loved it. This very popularity, though, sometimes made it suspect to the self-appointed guardians of academic standards, as did Brian's strong commitment to teaching as a primary responsibility of the department. One of his greatest achievements was to create an environment where everyone felt enabled and encouraged to develop and share their own interests - a genuine community without any sense of hierarchy, which both staff and students shared. Shortly before he retired, his department registered the highest grade in what was then the Research Assessment Exercise, and this was achieved not through a regime of performance management of staff but by creating the best kind of atmosphere for teaching and research.

He will be warmly remembered by generations of undergraduate and postgraduate students and colleagues who were lucky enough to have worked with him. 